\title{
INSECTS ASSOCIATED WITH THE FLOWERS OF TWO SPECIES OF MALACOTHRIX (ASTERACEAE) ON SAN MIGUEL ISLAND, CALIFORNIA
}

\author{
By Scott E. Miller ${ }^{1}$ ANd W. S. Davis ${ }^{2}$
}

The insects associated with Malacothrix incana (Nutt.) T. \& G. and $M$. implicata Eastwood on San Miguel Island were sampled as part of a general analysis of hybridization between the two species on the island (Davis and Philbrick, 1986). On San Miguel Island, $M$. incana is widely distributed on unstabilized and stabilized sand dunes on slopes near the ocean or on sandy substrate on the upper surfaces of the island including the slopes of. San Miguel Peak and Green Mountain. In contrast, $M$. implicata is generally restricted to the slopes near the ocean or the walls of canyons above the ocean. Hybrid plants were found only where $M$. incana and $M$. implicata were growing in a common area and constituted less than $1 \%$ of the total number of the three forms in these areas. Hybrid plants were most frequent on the slopes above Cuyler Harbor and above Tyler Bight.

Plants of $M$. implicata are spreading or erect perennials with large heads containing up to 80 florets. The ligules are white and have a purple stripe on the abaxial surface. Plants of $M$. incana are perennial and become mound-shaped after several years of growth. The large heads contain up to 100 florets with yellow ligules. The hybrid is also perennial and has large heads with pale yellow florets whose ligules often bear a reddish stripe on the abaxial surface.

During our visit to San Miguel Island in May, 1984 a majority of the plants of $M$. incana, $M$. implicata and the hybrid were in full bloom. Numerous open heads were present on plants of both species and one plant of $M$. incana had over 200 open heads. Herbarium label data indicate that the blooming period of $M$. incana generally coincides with that of $M$. implicata on other Channel Islands as well as on San Miguel Island and that flowering of both species reaches a maximum in the months of May and June.

\footnotetext{
'Museum of Comparative Zoology, Harvard University, Cambridge, Massachusetts 02138 and Dept. of Entomology, Smithsonian Institution, Washington, DC 20560. ${ }^{2}$ Department of Biology, University of Louisville, Louisville, Kentucky 40292. Manuscript received by the editor October 16, 1985.
} 
In cultivation, plants of $M$. incana have been found to be selfcompatible and all have had a chromosome number of $2 \mathrm{n}=14$ while plants of $M$. implicata have all been self-incompatible and have had a chromosome number of $2 \mathrm{n}=18$. The one hybrid plant propagated from wild fruit was sterile and 16 univalents were found in meiosis. Tests using long and short wave UV light $(366 \mathrm{~nm}$ and $245 \mathrm{~nm}$ ) on flower heads of plants in cultivation indicate that the reflective pattern of $M$. incana is quite different from that of $M$. implicata, and that the hybrid has the same pattern as in $M$. incana.

Because of the differences between $M$. incana and M. implicata in flower color, breeding system, and UV reflectance it was clear that a study of the pollinators of the two species would contribute to a general study of the causes of interspecific hybridization.

The only mention in the literature of insects on Malacothrix on San Miguel Island are the records of six native bee species at flowers of M. implicata by Cockerell (1937), the recent synonomy of one of these bees by Rust (1984), and there were no data on pollinator choice among the three flower types (Miller and Menke, 1981; Miller, 1985b).

\section{MeThods}

The present preliminary report is based on collections made on San Miguel Island, 24-27 May 1984, and data from Cockerell (1937), supplemented by earlier observations on this and other of the California Islands. On the May, 1984 trip most of the island was surveyed, with concentrated efforts on the slopes above Cuyler Harbor and Tyler Bight. Insect specimens are deposited in Santa Barbara Museum of Natural History, Natural History Museum of Los Angeles County, U.S. National Museum of Natural History, and California Department of Food and Agriculture collections. Our collecting emphasized sampling the diversity of insects present; time did not allow detailed observation of the abundance and activities of each species. Although our data are only preliminary, we feel that they are adequate to infer general patterns and suggest directions for future research, which should address seasonal and diurnal activity patterns of the insects, insect-flower interactions, and flower constancy of the insects (e.g. Hurd and Linsley, 1975; Hurd et al., 1980). 


\section{RESULTS}

In general, Malacothrix incana, M. implicata, and the interspecific hybrids are visited by the same suite of generalist bees and a few flies, as well as small beetles and true bugs (Table 1). Many of these species were seen on many other flowers in a variety of families including Convolvulaceae (Calystegia macrostegia subsp. macrostegia [Greene] Brummit) and Crassulaceae (Dudleya greenei Rose), in the Cuyler Harbor area. Because bees carry large pollen loads and move actively between flowers, they are probably the major pollinators of Malacothrix, although flies and beetles (as well as wasps which were not seen on flowers of Malacothrix on San Miguel Island) probably have some role in pollination.

It is probable that the most important pollinator is the native bee Agapostemon texanus Cresson, the relatively large metallic green females of which are abundant and active, especially in the early morning when the flowers of both species of San Miguel Island Malacothrix are open and receptive for pollination. Individuals of A. texanus were, in general, the most commonly observed bees on Malacothrix (although they were more obvious due to size and color than many of the small halictids), and were observed flying between Malacothrix flowers of the same and different colors. However, the relatively constant wind on the island made following individual bees for long periods impossible, so we have no data on flower preference or constancy. Pollen from the hind legs of eleven A. texanus females collected on Malacothrix was stained with cotton blue lactophenol and compared under a phase contrast light microscope with pollen of $M$. implicata and $M$. incana. The majority of the pollen grains from the bees were comparable to the pollen of Malacothrix in size, external wall structure, and other morphological characters although it was not possible to distinguish the pollen of $M$. incana from that of $M$. implicata. These observations are consistent with the biology of $A$. texanus in the laboratory (Roberts, 1969).

The insects found on flowers of Malacothrix on San Miguel Island in May, 1984 are listed in Table 1, which also includes records from Cockerell (1937). All of the taxa identified to species, except Lopidea nigridea hirta and the Hymenoptera, are San Miguel Island records first published here. All these species were 
Table 1. Pollinating and herbivorous insects known from flowers of Malacothrix on San Miguel Island $(\mathrm{X}=$ observed in May, 1984; Ckll = observed by Cockerell in July, 1937).

inc. impl. hyb.

Thysanoptera

Undetermined

$\mathrm{X}$

Thripidae

Frankliniella occidentalis (Pergande)

Thrips tabaci Lindeman

$\begin{array}{ll}\mathrm{X} & \mathrm{X} \\ \mathrm{X}\end{array}$

Hemiptera

Anthocoridae

Orius harpocrates Herring

Miridae

Lopidea nigridea hirta Van Duzee

$\begin{array}{ll}\mathrm{X} & \mathrm{X} \\ \mathrm{X} & \mathrm{X}\end{array}$

Coleoptera

Chrysomelidae

Diachus auratus (Fabricius)

Melyridae

Trichochrous (s. 1.) sp. A

Trichochrous (s. 1.) sp. B

$\mathrm{X}$

Staphylinidae

Tachyporus sp.

Bruchidae

Acanthoscelides napensis Johnson

Coccinellidae

Scymnus nebulosus LeConte

$\begin{array}{lll}\mathbf{X} & \mathbf{X} & \mathbf{X} \\ & & \\ \mathbf{X} & \mathbf{X} & \mathbf{X} \\ & \mathbf{X} & \end{array}$

Lepidoptera

Tortricidae

Argyrotaenia franciscana insulana

Powell (larvae)

$\mathbf{X}$

$\mathrm{X}$

$\mathrm{X}$

$\mathrm{X}$

Diptera

Syrphidae

Allograpta exotica (Wiedeman)

Carposcalis sp.

Copestylum mexicana (Macquart)

Sphaerophoria contiqua Macquart

Bombyliidae

Lepidanthrax borius Hall

$\begin{array}{lll} & & \mathrm{X} \\ \mathrm{X} & \\ \mathrm{X} & \mathrm{X} \\ \mathrm{X} & \end{array}$

Hymenoptera

Anthophoridae

Epeolus minimus (Robertson)

Ckll

$=E$. eastwoodae Cockerell

Hypochrotaenia suavis (Cresson) 
Table 1. (continued) Pollinating and herbivorous insects known from flowers of Malacothrix on San Miguel Island (X = observed in May, 1984; Ckll = observed by Cockerell in July, 1937).

inc. impl. hyb.

\author{
Apidae \\ Xeromelecta californica (Cresson) \\ Bethylidae \\ Goniozus sp. \\ Braconidae \\ Colletidae \\ Colletes hyalinus gaudalis Cockerell \\ Halictidae \\ Agapostemon texanus Cresson \\ $=A$. californicus psammobius Cockerell \\ Lasioglossum pavonotum (Cockerell) \\ Lasioglosum titusi (Crawford) \\ Dialictus megastictum (Cockerell) \\ Dialictus pilosicaudus (Cockerell) \\ Dialictus cabrilli (Cockerell) \\ Dialictus miguelensis (Cockerell) \\ Dialictus perichlarus (Cockerell) \\ Ichneumonidae \\ undetermined \\ Megachilidae \\ Anthidium palliventre Cresson \\ Pteromalidae \\ undetermined \\ undetermined
}

$\mathrm{X}$

Apanteles (s. 1.) sp. $\quad$ X

$\mathbf{X}$

$\mathrm{X} \quad \mathrm{X}, \mathrm{Ck}$ ll

X X, Ckll X

$\mathrm{X}$

$\mathrm{X} \quad \mathrm{X}, \mathrm{Ck}$ ll

Ckll

Ckll

$\begin{array}{ll}\mathrm{X} & \mathrm{X} \\ \mathrm{X} & \end{array}$

$\mathrm{X}$ 
collected on flowers, but some of them spend more time on leaves and stems than on flowers. The interspecific hybrid is somewhat more poorly represented with respect to its insects because fewer plants were seen. Lopidea nigridea hirta was described as a San Miguel Island endemic (Van Duzee, 1921), but the status of hirta (as species, subspecies or synonym of a more widespread species) is unclear without revision of the very large genus Lopidea. Two tortricid moth larvae were reared from the flowers of the hybrid Malacothrix (SEM lot 84E1A, B), yielding adult females of Argyrotaenia, probably franciscana insulana; the various island populations once lumped under insulana are quite variable and need review. Lepidanthrax borius is here first recorded from San Miguel and San Nicolas Islands; Cockerell's (1940: 292) San Nicolas record of L. angulus Osten Sacken might be a misidentification of this. The five species of Dialictus were described by Cockerell (1937, in the genus Halictus) from San Miguel island. Dialictus cabrilli is still considered a San Miguel Island endemic (Rust, in Miller, 1985a), but this may be due to the poor taxonomic condition of this difficult genus. Observations on other islands (Miller, unpubl.) and, specifically, from San Nicolas Island (Table 2) suggest that a similar suite of general pollinators is active on M. incana on other islands. Pollinator collections made on San Nicolas Island in May, 1984 were superficial compared to those on San Miguel Island, but consist of the same dominant elements.

Other parts of plants of Malacothrix were examined as well as flowers, and three families of Homoptera were found on stems and roots. The western aster root aphid, Aphis armoraceae Cowen (Aphididae) on the stem of a hybrid plant on the slopes above Cuyler Harbor, was associated with the introduced ant Lasius niger L. (Hymenoptera: Formicidae). The black scale, Saissetia oleae (Olivier) (Coccidae) was taken on stems of M. incana near Cabrillo Monument, Cuyler Harbor, in May, 1977 (by SEM) and on the slopes above Cuyler Harbor in May, 1984. An unidentified mealybug (Pseudococcidae) was taken from the root of a plant of $M$. implicata at Cuyler Harbor, but the specimen was lost in the mail during attempts to obtain an identification.

\section{CONCLUSIONS}

All the forms of Malacothrix on San Miguel Island are apparently visited by the same suite of generalist bees and a few flies, as 
Table 2. Associates of flowers of Malacothrix incana on San Nicolas Island (collected 11 and 31 May, 1984 by S. Junak from plants on stabilized sand dunes east of Corral Harbor, elevation about $20 \mathrm{~m}$ ).

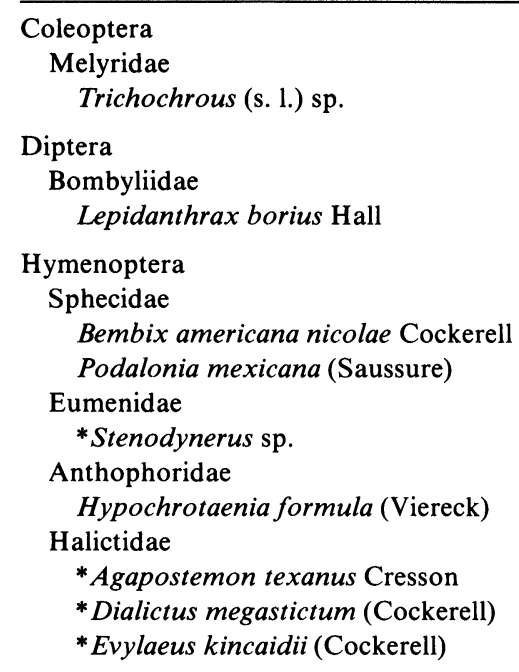

*Also collected on the hybrid Malacothrix incana $\times$ M. polycephala (ined.) 
well as small beetles and true bugs. Circumstantial evidence suggests that the bee Agapostemon texanus is probably the most important pollinator. Future research should examine the specific nature of the insect-flower interactions. The simplified nature (fewer species of both plants and pollinators compared to similar mainland sites) of insect-plant interaction systems on the California Islands presents excellent opportunities for testing hypotheses of insect-plant interaction and evolution (e.g. Cruden, 1972; Thorp, 1979).

\section{ACKNOWLEDGEMENTS}

We thank the National Park Service for permitting the research and for their assistance during the visit to San Miguel Island. Ralph N. Philbrick and Steve Junak, Santa Barbara Botanic Garden, enthusiastically assisted in fieldwork. We thank the following systematists for identifications: N. Evenhuis, Bishop Museum (Bombyliidae); R. J. Gill, California Department of Food and Agriculture (Coccidae); T. J. Henry, Systematic Entomology Laboratory, U.S.D.A. (Hemiptera); J. M. Kingsolver, SEL (Bruchidae and Melyridae); T. Kono, CDFA (Thysanoptera and Aphididae); A. S. Menke, SEL (Sphecidae); D. R. Miller, SEL (Coccidae); J. A. Powell, University of California, Berkeley (Tortricidae); T. N. Seeno, CDFA (Chrysomelidae); R. R. Snelling, Los Angeles County Museum (Apoidea); and F. C. Thompson, SEL (Syrphidae). R. J. McGinley, A. S. Menke, R. W. Rust, and R. R. Snelling reviewed the manuscript.

\section{Literature Cited}

Cockerell, T. D. A.

1937. Bees from San Miguel Island, California. Pan-Pac. Ent. 13: 148-157.

1940. The insects of the Californian Islands. Proc. Sixth Pacific Sci. Cong. 4: 283-295.

Cruden, R. W.

1972. Pollination ecology of Nemophila menziesii (Hydrophyllaceae) with comments on the evolution of oligolectic bees. Evol. 26: 373-389.

Davis, W. S. AND R. N. Philbrick

1986. Relationships in Malacothrix (Asteraceae); natural hybridization between $M$. implicata and $M$. incana. Submitted to Madroño.

Hurd, P. D., JR. AND E. G. LiNSLEY

1975. The principal Larrea bees of the southwestern United States (Hymenoptera: Apoidea). Smith. Cont. Zool. 193: 1-74.

Hurd, P. D., Jr., W. E. LaBerge, AND E. G. LinsLey

1980. Principal sunflower bees of North America with emphasis on the 
southwestern United States (Hymenoptera: Apoidea). Smith. Cont. Zool. 310: 1-158.

Miller, S. E. ANd A. S. Menke

1981. Entomological bibliography of the California Islands. Santa Barbara Museum of Natural History Occasional Papers. 11: 1-78.

MiLleR, S. E.

1985a. The California Channel Islands-Past, Present and Future: an Entomological Perspective. Pp 3-27 in A. S. Menke and D. R. Miller (eds), Entomology of the California Channel Islands: Proceedings of the First Symposium. Santa Barb. Mus. Nat. Hist.

1985b. Entomological bibliography of the California Islands. Supplement I. Pp. 137-169 in A. S. Menke and D. R. Miller (eds.), 1. c.

ROBERTS, R. B.

1969. Biology of the bee genus Agapostemon (Hymenoptera: Halictidae). Univ. Kansas Sci. Bull. 48: 689-719.

RUST, R. W.

1984. Synonomy in California Channel Island Epeolini bees (Hymenoptera: Anthophoridae). Pan-Pac. Ent. 60: 119-121.

THORP, R. W.

1979. Structural, behavioral, and physiological adaptations of bees (Apoidea) for collecting pollen. Ann. Miss. Bot. Gard. 66: 788-812.

VAN Duzee, E. P.

1921. Characters of some new species of North American hemipterous insects, with one new genus. Proc. Calif. Acad. Sci. (4) 11: 111-134. 

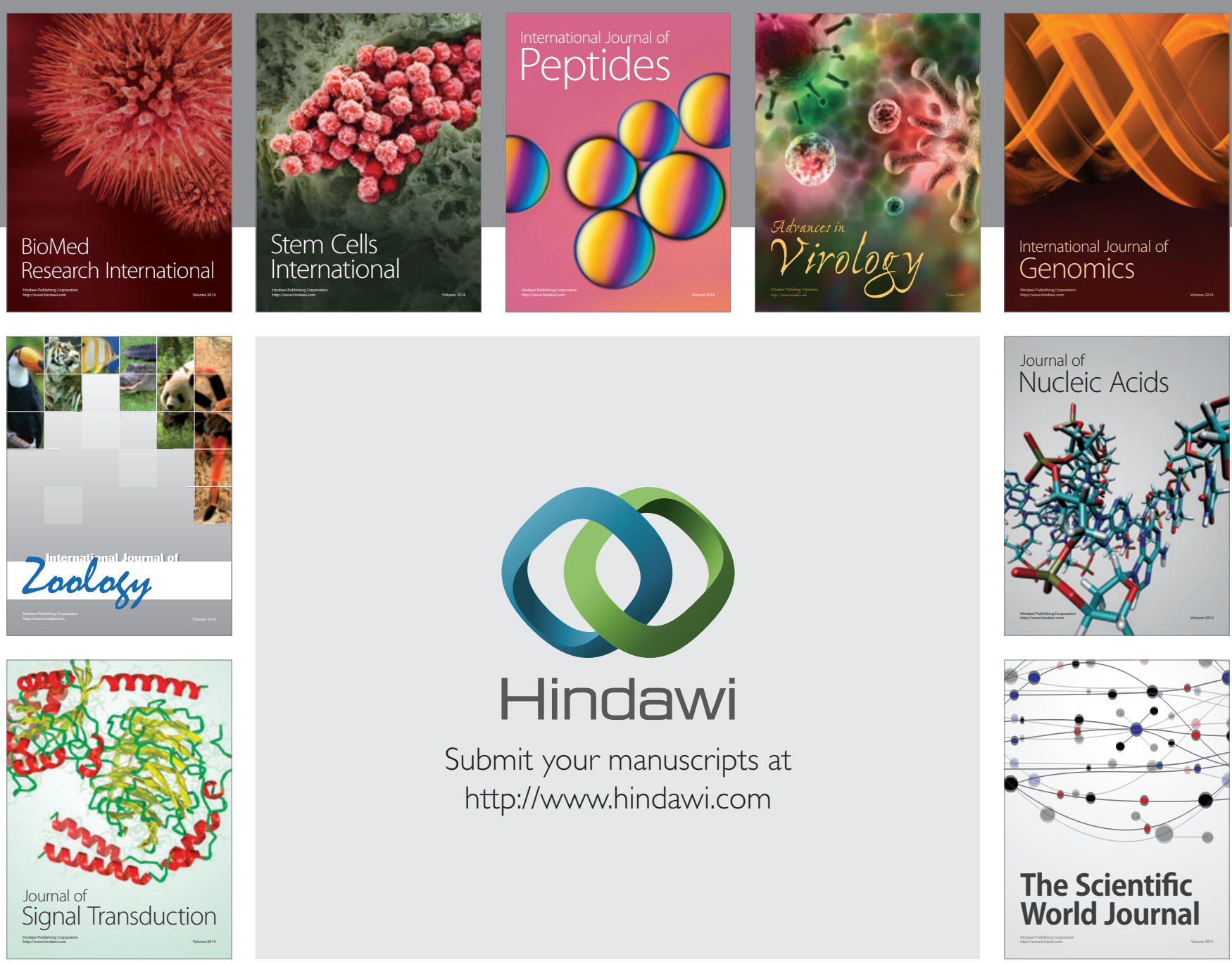

Submit your manuscripts at

http://www.hindawi.com
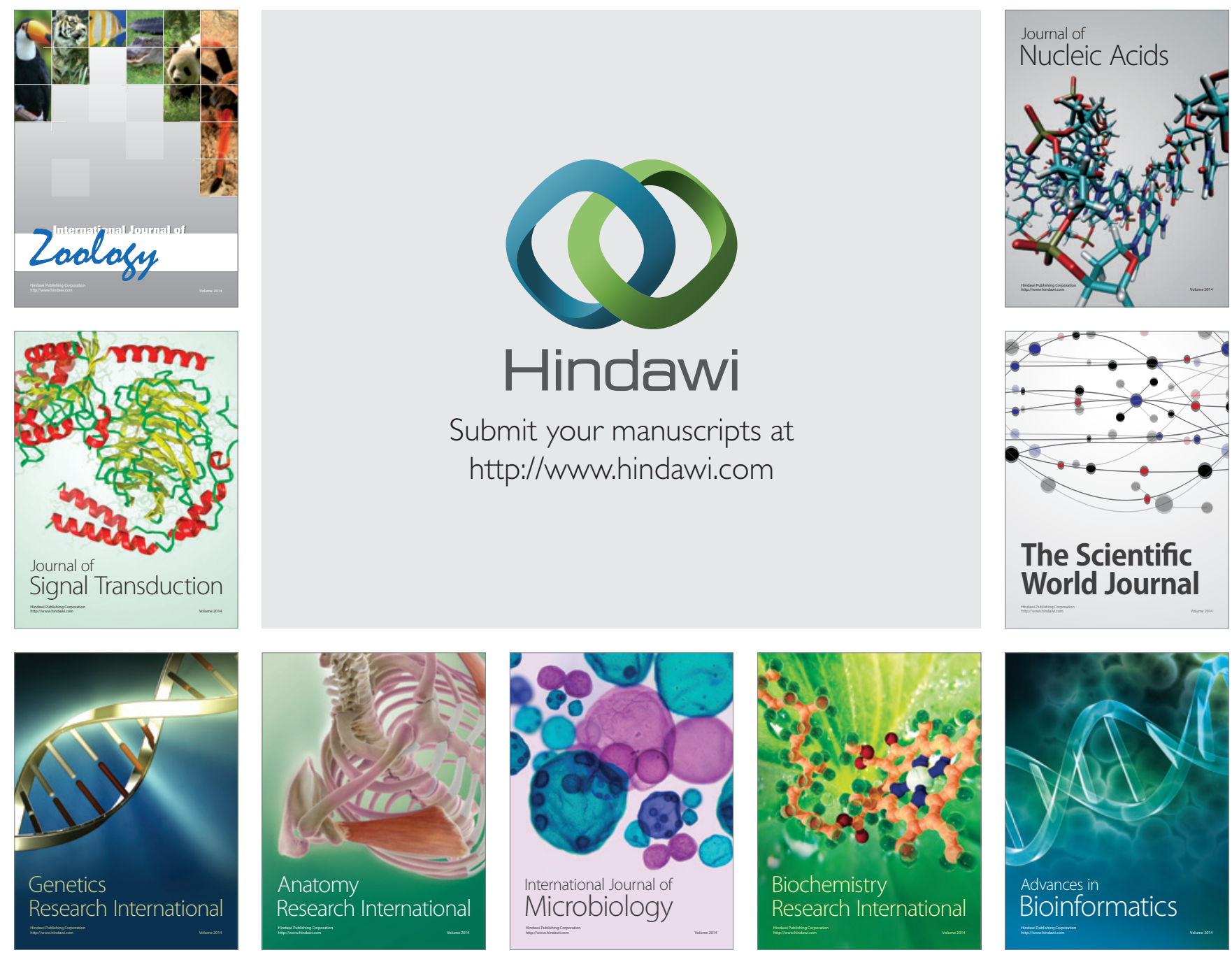

The Scientific World Journal
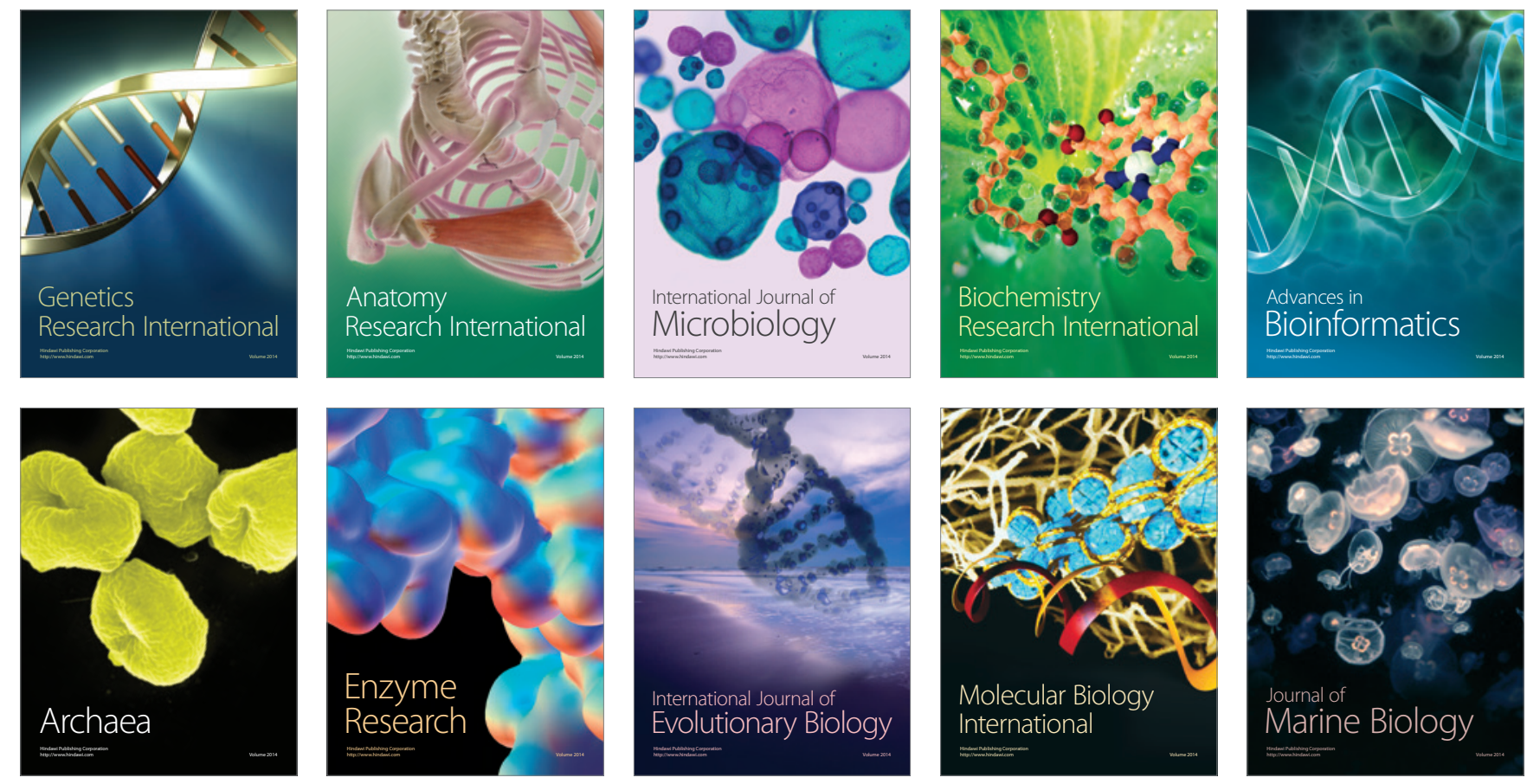